\title{
Is mechanical dispersion superior to global longitudinal strain in the assessment of patients with systemic lupus erythematosus?
}

\author{
Nilda Espinola-Zavaleta ${ }^{1,2}$
}

Published online: 20 May 2021

(C) The Author(s), under exclusive licence to Springer Nature B.V. 2021

Systemic lupus erythematosus (SLE) is a common systemic disease of the connective tissue, where cardiovascular diseases represent one of the most important causes of disability and mortality $[1,2]$. The prolonged disease duration (especially more than 10 years) and the high disease activity score (SLEDAI) were associated with the abnormalities in cardiac structure and function, although the precise mechanisms are unknown, these may be related to myocarditis caused by immune complex deposition and monocyte infiltration or by coronary artery disease, due to premature atherosclerosis, thrombosis, endothelial damage, inflammatory state mediated by immune complexes, renal involvement, hypertension, dyslipidemia, and the use of steroids [3, 4].

Echocardiography is a very useful non-invasive technique for the diagnosis of cardiac involvement in patients with SLE, but the conventional technique may be limited by the low sensitivity for early detection of myocardial dysfunction [5]. The use of speckle tracking echocardiography allows detailed analysis of left ventricular (LV) mechanics. Global longitudinal strain (GLS) has emerged as robust parameter of LV function and allows detection of subclinical LV dysfunction despite normal left ventricular ejection fraction (LVEF) [6, 7]. Mechanical dispersion (MD) is derived from LV longitudinal strain analysis and may cause regional heterogeneity of myocardial contraction. To quantify LV MD, we used the standard deviation (SD) of the 16 different time intervals to maximum myocardial shortening or delta contraction duration, which is defined as the difference between the longest and shortest time interval from ECG onset Q/ onset R-wave to the maximum myocardial shortening $[8,9]$.

Nilda Espinola-Zavaleta

niesza2001@ hotmail.com

1 Nuclear Cardiology Department, National Institute of Cardiology Ignacio Chavez, Juan Badiano $\mathrm{N}^{\circ}$ 1, Colonia Seccion XVI, Tlalpan, 14030 Mexico City, Mexico

2 Department of Echocardiography, ABC Medical Center, I.A.P, Mexico City, Mexico
Increased MD is associated with malignant arrhythmias in patients with ischemic heart disease and hypertrophic cardiomyopathy. Haugaa $\mathrm{KH}$ et al. found in the multivariate analysis of patients post myocardial infarction, that MD was a strong and independent predictor of arrhythmias $(p<0.001)$ in patients with an LVEF $>35 \%$ [10] and provides superior prognostic information to LVEF and GLS [9].

$\mathrm{Li} \mathrm{Ch}$ et al. studied 87 female patients with uncomplicated SLE and 59 healthy female controls using peak strain dispersion (PSD) within the LV detected by 2D speckle tracking. The SLE patients were divided into inactive disease $($ SLEDAI $<4)$ and active disease $($ SLEDAI $>5$ ). These authors found that PSD was more sensitive for inactive SLE patients whereas that GLS was a more vulnerable indicator of early left ventricular dysfunction in active SLE patients. The contribution by $\mathrm{Li}$ et al. also demonstrated that exists a positive correlation between disease activity and left ventricular function [11].

\section{Declarations}

Conflict of interest The author declare no conflicts of interest.

\section{References}

1. Jain D, Halushka MK (2009) Cardiac pathology of systemic lupus erythematosus. J Clin Pathol 62(7):584-592

2. Urowitz MB, Bookman AA, Koehler BE, Gordon DA, Smythe HA, Ogrzylo MA (1976) The bimodal mortality pattern of systemic lupus erythematosus. Am J Med 60:221-225

3. Doria A, Iaccarino L, Sarzi-Puttini P, Atzeni F, Turriel M, Petri M (2005) Cardiac involvement in systemic lupus erythematosus. Lupus 14:683-686

4. Ishimori ML, Martin R, Berman DS, Goykhman P, Shaw LJ, Shufelt C et al (2011) Myocardial ischemia in the absence of obstructive coronary artery disease in systemic lupus erythematosus. JACC Cardiovasc Imaging 4:27-33 
5. Gegenava T, Gegenava M, Steup-Beekman GM, Huizinga TWJ, Bax JJ, Delgado V et al (2020) Left ventricular systolic function in patients with systemic lupus erythematosus and its association with cardiovascular events. J Am Soc Echocardiogr 33:1116-1122

6. Marques-Alves P, Espirito-Santo N, Baptista R, Teixeira R, Martins R, Goncalves F et al (2018) Two-dimensional speckle-tracking global longitudinal strain in high-sensitivity troponin-negative low-risk patients with unstable angina: a "resting ischemia test"? Int J Cardiovasc Imaging 34(4):561-568

7. Kalam K, Otahal P, Marwick TH (2014) Prognostic implications of global LV dysfunction: a systematic review and metaanalysis of global longitudinal strain and ejection fraction. Heart 100(21):1673-1680

8. Zoghbi WA, Narula J (2010) Is mechanical dispersion a raven of ventricular arrhythmias? JACC Cardiovasc Imaging 3(3):330-331

9. Kvisvik B, Aagaard EN, Lars Mørkrid L, Røsjø H, Lyngbakken M, Marit Kristine Smedsrud MK et al (2019) Mechanical dispersion as a marker of left ventricular dysfunction and prognosis in stable coronary artery disease. Int J Cardiovasc Imaging 35(7):1265-1275

10. Huagaa KH, Smedsrud MK, Steen T, Kongsgaard E, Loennechen JP, Skjaeroe T et al (2010) Mechanical dispersion assessed by myocardial strain in patients after myocardial infarction for risk prediction of ventricular arrhytmia. J Am Coll Cardiol Imaging 2010(3):247-256

11. Li C, Li K, Yuan M, Bai W, Rao L (2021) Peak strain dispersion within the left ventricle detected by two-dimensional speckletracking in patients with uncomplicated systemic lupus eruthematosus. Int J Cardiovasc Imaging. https://doi.org/10.1007/ s10554-021-02201-7

Publisher's Note Springer Nature remains neutral with regard to jurisdictional claims in published maps and institutional affiliations. 